\title{
Disinfection with sodium hypochlorite in hospital environmental surfaces in the reduction of contamination and infection prevention: a systematic review*
}

\author{
Desinfecção com hipoclorito de sódio em superfícies ambientais hospitalares \\ na redução de contaminação e prevenção de infecção: revisão sistemática \\ Desinfección con hipoclorito de sodio en superficies ambientales hospitalarias en \\ la reducción de contaminación y prevención de infección: revisión sistemática
}

Samantha Storer Pesani Pereira ${ }^{1}$, Hadelândia Milon de Oliveira ${ }^{2}$, Ruth Natalia Teresa Turrini ${ }^{1}$, Rúbia Aparecida Lacerda ${ }^{1}$

*Extracted from the Scientific Initiation Project PIBIC "Desinfecção de superfícies ambientais hospitalares com hipoclorito de sódio e redução de infecção ou contaminação: uma revisão sistemática”, Escola de Enfermagem, Universidade de São Paulo, 2014

${ }^{1}$ Universidade de São Paulo, Escola de Enfermagem, Departamento de Enfermagem Médico-Cirúrgica, São Paulo, SP, Brazil.

${ }^{2}$ Universidade de São Paulo, Escola de Enfermagem, Programa de Pós-Graduação em Enfermagem na Saúde do Adulto, São Paulo, SP Brazil.

\section{ABSTRACT}

Objective: To search for evidence of the efficiency of sodium hypochlorite on environmental surfaces in reducing contamination and prevention of healthcareassociated infection HAIs. Method: Systematic review in accordance with the Cochrane Collaboration. Results: We analyzed 14 studies, all controlled trials, published between 1989-2013. Most studies resulted in inhibition of microorganism growth. Some decreased infection, microorganism resistance and colonization, loss of efficiency in the presence of dirty and surface-dried viruses. Conclusion: The hypochlorite is an effective disinfectant, however, the issue of the direct relation with the reduction of HAIs remains. The absence of control for confounding variables in the analyzed studies made the metaanalysis performance inadequate. The evaluation of internal validity using CONSORT and TREND was not possible because its contents were not appropriate to laboratory and microbiological studies. As a result, there is an urgent need for developing specific protocol for evaluating such studies.

\section{DESCRIPTORS}

Disinfection; Sodium Hypochlorite; Health Facilities; Cross Infection; Review. 


\section{INTRODUCTION}

Over 30 years ago, Spaulding established an approach to the treatment of hospital equipment, classifying them according to their potential risk of contamination and transmission of infection in: critical, semi-critical and non-critical items ${ }^{(1)}$. This classification also founded several guidelines recommendations for aseptic procedures ${ }^{(2-5)}$.

According to this classification, the critical items are those which come into direct contact with sterile tissues or vascular system as well as other items that are connected to them. They, therefore, need sterilization. The semi-critical items come into contact with mucous membranes or nonintact skin. In these cases, high-level disinfection is recommended. And non-critical items come in contact with intact skin, but not mucous membranes, so the only recommendation is cleaning ${ }^{(1)}$.

In 1991, the Centers for Disease Control and Prevention (CDC) proposed an additional category to the original Spaulding classification for non-critical items called environmental surfaces which, in turn, can be divided into equipment surfaces (X-ray apparatus, hemodialysis machine etc.) and housekeeping surfaces (furniture, floor, wall, table top etc. $)^{(6)}$.

There are still doubts about the treatment to be given to environmental surfaces. Theoretically, if included as non-critical items in the original Spaulding classification, they only need cleaning ${ }^{(1)}$. But the Disinfection and Sterilization in Healthcare Facilities guidelines proposed by CDC considers that environmental surfaces are frequently touched by hands and may potentially contribute to secondary transmission by contaminated hands of health professionals or by contact of medical equipment, which are subsequently used in patients ${ }^{(4)}$. It is also known that certain microorganisms that cause healthcare-associated infections (HAIs) are resistant to common cleaning processes, survive for long periods on surfaces under dry conditions and can be transferred not only through hands, but also by air movement in the environment ${ }^{(7)}$. Such considerations have been referred to defend the disinfection and not just cleaning environmental surfaces.

Virtually, the risk of transmission of infection by noncritical items has not been documented ${ }^{(7)}$. However, a systematic review has shown that available studies do not yet allow a conclusion and, given the complex and multifactorial nature of HAIs, well-designed studies that systematically investigate the role of disinfecting surfaces in the transmission of infection are still needed ${ }^{(8)}$. In turn, the National Evidence-Based Guide Related to Infection Prevention in Health Care (epic3), instead of generalizing the treatment of any item recommend levels of cleaning or disinfection procedures, according to circumstances of use, contamination and occurrences of cases of colonization or infection ${ }^{(9)}$.

Despite the new products and new technologies for disinfection procedures, sodium hypochlorite is still one of the most widely used and accessible products in terms of cost and benefit. This study intends to seek evidence on their efficiency on environmental surfaces in reducing contamination and prevention of healthcare-associated infections - HAIs.

\section{METHOD}

A systematic review in accordance with the recommendations of the Cochrane Collaboration was conducted. The searches were performed from December 2013 to February 2014 in the databases COCHRANE, LILACS, PubMed/ MEDLINE, SciELO, CINAHL, in addition to references cited in the studies found. We used the PICO strategy: Participants $=$ tests in situ or in vitro with microorganisms commonly isolates from environmental surfaces and medical equipment; Intervention = sodium hypochlorite applica tion; Comparison $=$ other products or different concentrations of hypochlorite; Outcome = degree of colonization reduction, contamination or microorganism resistance, or prevention of HAIs.

The inclusion criteria were: primary studies without language restriction and publication period, obtained in full. Exclusion criteria were: multimodal interventions, the lack of use of sodium hypochlorite and the non-use of the product on laboratory surfaces.

For the selection of the descriptors, we used the tools provided by CINAHL (Cumulative Index to Nursing and Allied Health Literature), MeSH (Medical Subject Headings Section) of the PubMed/MEDLINE and DeCS (Health Sciences Descriptors) and Synonyms combinations of terms obtained by means of prior readings, resulting in combinations: "sodium hypochlorite/pharmacology" AND "disinfection/methods" AND hospitals AND surfac" / "infections control/methods" AND "environmental microbiology" AND hospitals AND surfac" /"cross infection" AND "sodium hypochlorite" / "sodium hypochlorite/pharmacology" AND hospitals. The search strategy used was the same for each database, the screening was performed for more than two reviewers.

The data analysis criteria followed the steps: 1) screening of studies; 2) study characteristics (methodological design, scope, setting, tested microorganism, sodium hypochlorite concentration, outcome, conclusion); 3) analysis of evidence provided by TREND protocol version 1.0 (designed for non-randomized studies)(10) and CONSORT (designed for randomized trials) ${ }^{(11)}$, if their applications were possible.

\section{RESULTS}

Figure 1 shows the result of the flow chart diagram. There was a predominance of studies from PubMed/Medline (99), followed by CINAHL (66), LILACS (7), SciELO (3) and COCHRANE (1). Most studies were excluded because they were duplicates, not primary study, did not meet the question asked, or was not possible to obtain the full-text to apply the inclusion or exclusion criteria. Of the 26 remaining studies after reading in full, the other 12 studies were excluded since they are simultaneous multiinterventions, they did not test the sodium hypochlorite or have it tested in non-environmental surface or tested along with other products, preventing recognition of their isolates effect. Thus, 14 studies were included. 


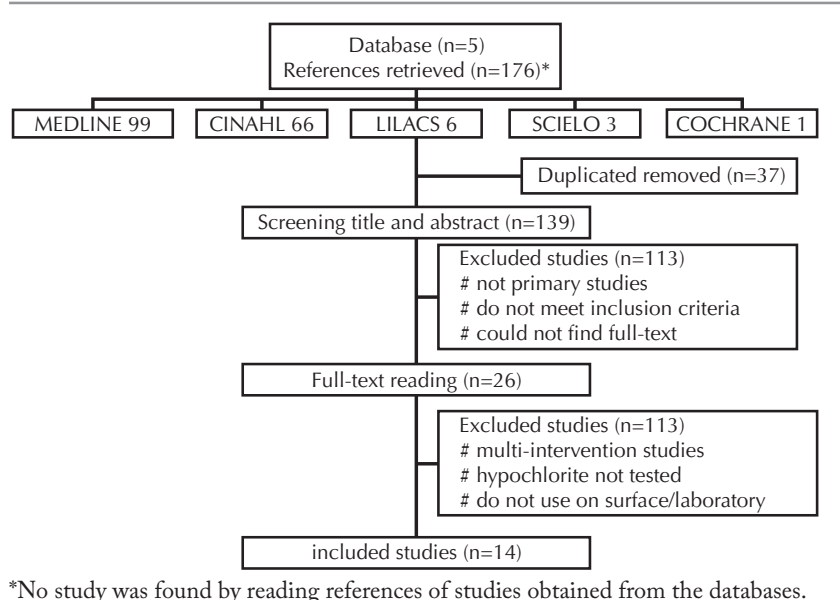

Figure 1 - Selection process of studies in the databases - Sao Paulo, SP, Brazil, 2014

A total of five full-text studies not found were excluded: 1) Hoefel HHK, Porto BS, Petrillo VF. Soluções germicidas e detergentes para uso no Hospital de Clinicas de Porto Alegre/Desinfetantes e sabonetes. Rev. HCPA Fac. Med. Univ. Fed. Rio Gd. Sul 1988;8(3):208-11; 2) Coates D. Disinfec- tants and spills of body fluids. Nurs RSA. 1992 Jun;7(6):257;3) Kaboth U,Junge U. Prophylaxis of viral hepatitis. Clin Gastroenterol. 1974 May;3(2):453-70; 4) Carswell JW. Precautions against HIV transmission in hospitals. Trop Doct. 1989 Jul;19(3):131-2; 5) Lehman HH. Flame-resistant fabrics. Hospitals. 1973 Oct 16;47(20):98-106.

Of the included studies, 12 were published in the twenty-first century, four studies in the last decade (2010-2013). Only two were published in the previous century (19891999). The publications were mainly on internationally recognized and specialized journals on the topic of HAIs: Infection Control and Hospital Epidemiology (5); Journal of Hospital Infection (5); American Journal of Infection Control (2). Two were published in Brazil, one of them also in a specialized journal on the topic of HAIs (Brazilian Journal of Microbiology) and another in a general nursing journal (Ciência, Cuidado e Saúde).

Table 1 presents a summary of the included studies, containing scope, types of study, testing and outcome, investigated microorganisms, hypochlorite concentrations applied and conclusion.

Table 1 - Synthesis and evaluation of the studies included in the systematic review - Sao Paulo, SP, Brazil, 2014.

\begin{tabular}{|c|c|c|c|c|c|c|c|}
\hline Ref. & $\begin{array}{l}\text { Type of } \\
\text { study }\end{array}$ & Scope & Setting & Microorganism & Outcome & $\begin{array}{c}\text { Concentration } \\
\text { of Sodium } \\
\text { hypochlorite }\end{array}$ & $\begin{array}{c}\text { Conclusion on hypochlorite } \\
\text { efficiency }\end{array}$ \\
\hline 12 & $\begin{array}{l}\text { Controlled } \\
\text { trial* }\end{array}$ & $\begin{array}{l}\text { Bacterial } \\
\text { resistance to } \\
\text { antiseptics and } \\
\text { disinfectants in } \\
\text { two hospitals. }\end{array}$ & In vitro & $\begin{array}{l}\text { MRSA (isolates } \\
\text { from surface. } \\
\text { environmental } \\
\text { and ICU } \\
\text { equipment) }\end{array}$ & $\begin{array}{l}\text { Microbial } \\
\text { resistance }\end{array}$ & $\begin{array}{l}0.05 \% \\
0.1 \% \\
0.2 \%\end{array}$ & $\begin{array}{l}\text { Effectiveness similar to } 1 \% \text { and } 2 \% \\
\text { hypochlorite, } 2 \% \text { chlorhexidine, } \\
2 \% \text { quaternary ammonium } \\
2 \% \text { peracetic acid and } 10 \% \\
\text { formaldehyde. Less effective for } \\
4 \% \text { acetic acid, } 70 \% \text { ethanol and } \\
2 \% \text { glutaraldehyde. }\end{array}$ \\
\hline 13 & $\begin{array}{l}\text { Controlled } \\
\text { trial* }\end{array}$ & $\begin{array}{l}\text { Effects of } \\
\text { hospital } \\
\text { cleaning and } \\
\text { disinfectant } \\
\text { agents and } \\
\text { survival of } \\
\text { the epidemic } \\
\text { resistant } \\
\text { bacteria. }\end{array}$ & In vitro & $\begin{array}{l}\text { C. difficile } \\
\text { spore and } \\
\text { vegetative } \\
\text { (isolates from } \\
\text { human faecal } \\
\text { emulsion ) }\end{array}$ & $\begin{array}{l}\text { Microbial } \\
\text { inactivation }\end{array}$ & $\begin{array}{c}0.5 \% \\
\text { detergent }\end{array}$ & $\begin{array}{l}\text { All products and concentrations } \\
\text { (3-Chloro-based formulations, } 1 \\
\text { detergent and } 1 \text { hydrogen peroxide) } \\
\text { inhibited growth in culture, } \\
\text { however, in traditional hypochlorite } \\
\text { concentrations were only able to } \\
\text { inactivate spores. }\end{array}$ \\
\hline 14 & $\underset{\text { trial* }}{\text { Controlled }}$ & $\begin{array}{l}\text { Phenolic } \\
\text { X Sodium } \\
\text { hypochlorite, } \\
\text { cleaned, dirty } \\
\text { conditioned } \\
\text { and } \\
\text { contaminated } \\
\text { with blood and } \\
\text { bodily fluids. }\end{array}$ & In vitro & $\begin{array}{l}\text { S. aureus } \\
\text { (NCTC4163), } \\
\text { E. coli (NCTC } \\
\text { 8196), P aeru. } \\
\text { Ginosa (NCTC } \\
6570)\end{array}$ & $\begin{array}{l}\text { Microbial } \\
\text { inactivation }\end{array}$ & $0.25 \%$ & $\begin{array}{l}\text { Phenolics and hypochlorites } \\
\text { are substantially inactivated in } \\
\text { the presence of organic matter. } \\
\text { Sodium hypochlorite, even at } \\
\text { high concentration (10000ppm) } \\
\text { and phenol may be ineffective } \\
\text { for treating blood splash applied } \\
\text { to } 9 \text { parts of disinfectant to } 1 \text { part } \\
\text { of blood. }\end{array}$ \\
\hline 15 & $\begin{array}{c}\text { Controlled } \\
\text { trial* }\end{array}$ & $\begin{array}{c}\text { Sodium } \\
\text { hypochlorite } \\
\text { Action X } \\
\text { peracetic acid. }\end{array}$ & In vitro & $\begin{array}{l}\text { MRSA (isolates } \\
\text { case of hospital } \\
\text { infection) }\end{array}$ & $\begin{array}{l}\text { Microbial } \\
\text { inactivation }\end{array}$ & $0.1 \%$ & $\begin{array}{l}\text { Both disinfectants were equivalent } \\
\text { after } 5 \text { minutes of contact with } \\
\text { MRSA suspension. The increased } \\
\text { time for } 10 \text { min intensified action, } \\
\text { allowing the death of the bacteria } \\
\text { at concentrations of each of the two } \\
\text { disinfectants } 10 \text { times lower }\end{array}$ \\
\hline 16 & $\begin{array}{c}\text { Controlled } \\
\text { trial* }\end{array}$ & $\begin{array}{l}\text { Action of } \\
\text { oxidizing } \\
\text { microbicides in } \\
\text { soiled surfaces } \\
\text { in relatively } \\
\text { short contact } \\
\text { times at room } \\
\text { temperature. }\end{array}$ & In vitro & $\begin{array}{l}\text { C. difficile ( } \\
\text { clinical isolate } \\
\text { spores) }\end{array}$ & $\begin{array}{l}\text { Microbial } \\
\text { inactivation }\end{array}$ & $\begin{array}{c}0.1 \%, 3 \% \\
0.5 \% \text { and } \\
0.5 \% \\
\text { acidified }\end{array}$ & $\begin{array}{l}\text { All inactivate spores in times } \\
\text { depending on the concentration. } \\
\text { Hypochlorite and hypochlorite } \\
\text { acidified regular 5000mg/L } 10 \\
\text { minutes; regular hypochlorite } \\
\text { 3000mg/L: } 20 \text { minutes; Hydrogen } \\
\text { peroxide: } 13 \text { minutes; chlorine } \\
\text { dioxide and hypochlorite regular } \\
\text { 1000mg/L: } 30 \text { minutes. }\end{array}$ \\
\hline
\end{tabular}




\begin{tabular}{|c|c|c|c|c|c|c|c|}
\hline Ref. & $\begin{array}{l}\text { Type of } \\
\text { study }\end{array}$ & Scope & Setting & Microorganism & Outcome & $\begin{array}{c}\text { Concentration } \\
\text { of Sodium } \\
\text { hypochlorite }\end{array}$ & $\begin{array}{l}\text { Conclusion on hypochlorite } \\
\text { efficiency }\end{array}$ \\
\hline 17 & $\begin{array}{l}\text { Controlled } \\
\text { trial* }\end{array}$ & $\begin{array}{l}\text { Antiseptics } \\
\text { and detergents } \\
\text { action against } \\
\text { Candidas. }\end{array}$ & In vitro & $\begin{array}{l}\text { albicans, } \\
\text { tropicalis, } \\
\text { lusitaniae, } \\
\text { parapsilosis, } \\
\text { kefyr, labrata } \\
\text { (clinical } \\
\text { isolates) }\end{array}$ & $\begin{array}{l}\text { Growth } \\
\text { inactivation }\end{array}$ & $5.25 \%$ & $\begin{array}{l}\text { Varying degrees of growth } \\
\text { inhibition as applied product } \\
\text { (4\% chlorhexidine alcohol, } 10 \% \\
\text { povidone, 3\% chloroxylenol; } 5.25 \% \\
\text { sodium hypochlorite) hypochlorite } \\
\text { showed growth inhibition after } 30 \\
\text { seconds of contact. }\end{array}$ \\
\hline 18 & $\begin{array}{l}\text { Controlled } \\
\text { trial* }\end{array}$ & $\begin{array}{l}\text { Germicidal } \\
\text { activity of two } \\
\text { antiseptic and } \\
\text { one hospital } \\
\text { disinfectant } \\
\text { after } 5 \text { minutes } \\
\text { of contact. }\end{array}$ & In vitro & $\begin{array}{l}\text { Gram- } \\
\text { susceptible } \\
\text { and resistant } \\
\text { (isolates from } \\
\text { University and } \\
\text { hospital) }\end{array}$ & $\begin{array}{l}\text { Microbial } \\
\text { reduction }\end{array}$ & $\begin{array}{l}0.01 \% \\
0.1 \%\end{array}$ & $\begin{array}{l}\text { Although with significant variations } \\
\text { depending on the concentration. } \\
\text { A } 0.1 \% \text { was effective against } \\
92.2 \% \text { of all strains after } 5 \text { minutes. } \\
\text { Similar effect for antiseptic ( } 4 \% \\
\text { chlorhexidine chlorhexidine with } \\
\text { cetrimide). } 0.01 \% \text { Hypochlorite } \\
\text { decreased significantly the effect. }\end{array}$ \\
\hline 19 & $\begin{array}{l}\text { Controlled } \\
\text { trial* }\end{array}$ & $\begin{array}{l}\text { Bactericidal } \\
\text { activity } \\
\text { against five } \\
\text { disinfectants } \\
\text { isolates } \\
\text { from various } \\
\text { environmental } \\
\text { surfaces and } \\
\text { microorganisms } \\
\text { susceptible } \\
\text { and resistant } \\
\text { equipment to } \\
\text { antibiotics. }\end{array}$ & In vitro & $\begin{array}{c}\text { MRSA, E. spp, } \\
\text { P. aeruginosa, } \\
\text { K. Methicillin- } \\
\text { resistant } \\
\text { pneumoniae, } \\
\text { S. aureus, S. } \\
\text { epidermidis, S. } \\
\text { haemolyticus, } \\
\text { S. marces } \\
\text { cens, E. cloa } \\
\text { cae, E. coli, P. } \\
\text { mirabilis }\end{array}$ & $\begin{array}{l}\text { Microbial } \\
\text { inactivation }\end{array}$ & $0.5 ; 1 \% ; 2 \%$ & $\begin{array}{l}\text { The most effective disinfectants } \\
\text { were hypochlorite and aldehydes. } \\
\text { Phenolic and quaternary ammonium } \\
\text { need to be used at higher } \\
\text { concentrations than suggested in } \\
\text { the literature. Out of } 21 \text { strains } \\
\text { resistant to antibiotics, } 11(52 \%) \text { and } \\
8(38 \%) \text { were resistant to quaternary } \\
\text { ammonia and phenolic compounds, } \\
\text { respectively. Among the six isolates } \\
\text { susceptible to the antibiotic, two } \\
\text { (33\%) showed the same resistance to } \\
\text { disinfectants. Wide diversity and lack } \\
\text { of correlation between susceptibility } \\
\text { to antibiotics and susceptibility } \\
\text { to disinfectants in the hospital } \\
\text { strains. No statistically significant } \\
\text { difference of action for resistant and } \\
\text { susceptible strains. }\end{array}$ \\
\hline 20 & $\begin{array}{c}\text { Controlled } \\
\text { before and } \\
\text { after, } \\
\text { Randomized } \\
\text { for surface. }\end{array}$ & $\begin{array}{l}\text { Surfaces daily } \\
\text { cleaning with } \\
\text { quaternary } \\
\text { ammonium } \\
\text { (before) } \\
\text { and sodium } \\
\text { hypochlorite } \\
\text { (after) in high } \\
\text { incidence areas } \\
\text { of infection }\end{array}$ & $\begin{array}{l}\text { In situ } \\
\text { (rooms and } \\
\text { surface of } \\
\text { frequent } \\
\text { touch) }\end{array}$ & C. difficile & Infection & $0.55 \%$ & $\begin{array}{l}\text { Reduction of incidence of } \mathrm{C} \text {. } \\
\text { difficile infection in } 85 \% \text { of } 24.2 \\
\text { to } 3.6 \text { cases per } 10,000 \text { patient- } \\
\text { days and prolongation of the mean } \\
\text { time between the cases of } 8 \text { to } 80 \\
\text { days. However, there is recognition } \\
\text { of the limitations to control } \\
\text { all confounders. }\end{array}$ \\
\hline 21 & $\begin{array}{c}\text { Controlled } \\
\text { before and } \\
\text { after } \\
\text { Randomized } \\
\text { for surface }\end{array}$ & $\begin{array}{l}\text { dry steam } \\
\text { hydrogen } \\
\text { peroxide X } \\
\text { hypochlorite in } \\
\text { the disinfection } \\
\text { of surfaces. }\end{array}$ & In situ & $\begin{array}{c}\text { C. difficile } \\
\text { (isolates floors } \\
\text { and furniture of } \\
\text { patient rooms ) }\end{array}$ & $\begin{array}{c}\text { Contamination } \\
\text { reduction }\end{array}$ & $0.5 \%$ & $\begin{array}{l}\text { But significantly lower reduction to } \\
\text { the dry steam of hydrogen peroxide } \\
\text { - System of dry steam hydrogen } \\
\text { peroxide: } 91 \% \\
\text { - Sodium hypochlorite: } 50 \%\end{array}$ \\
\hline 22 & $\begin{array}{l}\text { Controlled } \\
\text { trial* }\end{array}$ & $\begin{array}{l}\text { Infection } \\
\text { before and } \\
\text { after exchange } \\
\text { of disinfectant } \\
\text { for final } \\
\text { cleaning in } 3 \\
\text { hospitals. }\end{array}$ & $\begin{array}{l}\text { In situ } \\
\text { (room and } \\
\text { equipment } \\
\text { surfaces }\end{array}$ & $\begin{array}{l}\text { C. difficile } \\
\text { (isolates from } \\
\text { infected } \\
\text { patients) }\end{array}$ & Infection & $0.5 \%$ & $\begin{array}{c}\text { Reduced incidence of infection } \\
\text { of } 0.85 \text { to } 0.45 \text { and reduction of } \\
\text { the prevalence in } 48 \% \text { for the two } \\
\text { intervention years, compared to the } \\
\text { quaternary ammonium. }\end{array}$ \\
\hline 23 & $\begin{array}{l}\text { Controlled } \\
\text { trial* }\end{array}$ & $\begin{array}{c}\text { Infection } \\
\text { during } \\
\text { outbreak } \\
\text { and after } \\
\text { intervention } \\
\text { with } \\
\text { disinfection } \\
\text { in a medical } \\
\text { ICU and other } \\
\text { surgical ICU } \\
\text { in two phases: } \\
2012 \text { and } \\
2013 .\end{array}$ & $\begin{array}{c}\text { In situ } \\
\text { (surface } \\
\text { and } \\
\text { equipment) }\end{array}$ & C. difficile & Infection & $0.5 \%$ & $\begin{array}{c}\text { Significant reduction of } C \text {. difficile } \\
\text { infection } \\
\text { Medical ICU: } 16.6 \text { to } 3.7 \text { cases/1000 } \\
\text { patient-days in the first stage and } \\
2.8 \text { in the second stage; Surgical } \\
\text { ICU: } 10.4 \text { to } 3.9 \text { cases/1000 patient- } \\
\text { days in the first stage and } 2.2 \text { in the } \\
\text { second stage. }\end{array}$ \\
\hline
\end{tabular}

continued... 


\begin{tabular}{|c|c|c|c|c|c|c|c|}
\hline Ref. & $\begin{array}{l}\text { Type of } \\
\text { study }\end{array}$ & Scope & Setting & Microorganism & Outcome & $\begin{array}{c}\text { Concentration } \\
\text { of Sodium } \\
\text { hypochlorite }\end{array}$ & $\begin{array}{l}\text { Conclusion on hypochlorite } \\
\text { efficiency }\end{array}$ \\
\hline 24 & $\begin{array}{l}\text { Controlled } \\
\text { trial, cross- } \\
\text { over }\end{array}$ & $\begin{array}{c}\text { Sodium } \\
\text { hypochlorite } \\
\text { X neutral } \\
\text { detergent } \\
\text { in reducing } \\
\text { infection. }\end{array}$ & $\begin{array}{l}\text { In situ } \\
\text { (two } \\
\text { hospital } \\
\text { areas) }\end{array}$ & C. difficile & Infection & $\begin{array}{l}\text { 1000ppm } \\
0.1 \%\end{array}$ & $\begin{array}{l}\text { Area cleaned with hypochlorite: } \\
\text { significant reduction of infection: } 8.9 \\
\text { to } 5.3 \text { cases / } 100 \text { admissions. Clean } \\
\text { area with detergent: no significant } \\
\text { effect. There is some evidence } \\
\text { that hypochlorite for cleaning } \\
\text { environmental surfaces significantly } \\
\text { reduces the incidence of C. difficile } \\
\text { infection, but emphasizes the } \\
\text { potential for confounding factors. }\end{array}$ \\
\hline 25 & $\begin{array}{l}\text { Controlled } \\
\text { trial* }\end{array}$ & $\begin{array}{l}\text { Various virus } \\
\text { persistence } \\
\text { in dry } \\
\text { surfaces and } \\
\text { disinfecting } \\
\text { effect on the } \\
\text { infectivity of } \\
\text { viruses with } \\
\text { and without } \\
\text { rehydration } \\
\text { before } \\
\text { disinfection. }\end{array}$ & $\begin{array}{c}\text { In vitro } \\
\text { (isolate in } \\
\text { plasma and } \\
\text { culture) }\end{array}$ & $\begin{array}{l}\text { lipid and non- } \\
\text { lipid virus } \\
\text { enveloped } \\
\text { transmitted } \\
\text { by the human } \\
\text { and nonhuman } \\
\text { blood }\end{array}$ & $\begin{array}{c}\text { Virus } \\
\text { inactivation }\end{array}$ & $0.1 \%$ & $\begin{array}{l}\text { Infectious virus remained for long } \\
\text { periods on surfaces when dry. All } \\
\text { disinfectants tested (9.1\% sodium } \\
\text { hypochlorite, } 80 \% \text { ethanol, } 0.1 \\
\text { NaOH) significantly reduced } \\
\text { the survival of the dry virus, but } \\
\text { rehydration in plasma offered } \\
\text { protective effect, reducing their } \\
\text { actions. Hypochlorite resulted in a } \\
\text { reduction of }>4 \text { log for all viruses } \\
\text { under dry conditions, but limited } \\
\text { when rehydrated in plasma, except } \\
\text { for HIV and PRV that had complete } \\
\text { inactivation. }\end{array}$ \\
\hline
\end{tabular}

All studies used interventions and tested the action of sodium hypochlorite. Regarding the type of intervention, they are divided between those which conducted tests only in laboratory (in vitro) ${ }^{(12-19)}$ and those which tested samples directly (in situ) in various environmental surfaces: floors, walls, equipment etc. ${ }^{(20-24)}$. Thus, all induced microbiologi$\mathrm{cal}$ tests. Among the tested microorganisms, most strains represented clinical isolates from patients or surfaces and equipment, being resistant to several antibiotics. The most tested microorganism was C. difficile ${ }^{(13,16,20-24)}$, followed by S. aureus, MRSA or not ${ }^{(12,14-15,19)}$, various species of Candida ${ }^{(17)}$ and lipophilic viruses ${ }^{(25)}$, various $\mathrm{Gram}^{(18)}, E$. $\operatorname{col}^{(14)}$ and others ${ }^{(19)}$.

Only four studies sought, as an outcome, a direct correlation between microbicidal action of disinfectant and infection rates ${ }^{(20,22-24)}$. Most of them were correlated to inactivation rates, reduction or inhibition of microbial growth ${ }^{(13,15-19,21,25)}$. Furthermore, a study tested the outcome microbial resistance $^{(12)}$. With two exceptions ${ }^{(14,25)}$, the other studies presented results favorable to the action of sodium hypochlorite to the proposed outcomes, either for inactivation or inhibition of microbial growth ${ }^{(13,15-19,21)}$, reduction of infection ${ }^{(20,22-24)}$, microbial resistance ${ }^{(12)}$. Among the exceptions, one of them showed loss of efficiency in a situation of heavy dirtying with organic matter ${ }^{(14)}$. The other was effective for dry viruses, but not in the presence of rehydrated virus ${ }^{(25)}$.

Although in most studies the results have been favorable to the action of hypochlorite, efficiency varied according to time of exposure and concentration. The concentrations ranged from $0.01 \%$ to $5.25 \%$. Similarly, the concentrations of the products used for comparison.

The hypochlorite was superior to quaternary ammonium $^{(13,19,22,25)}$, composed by quaternary ammonium ${ }^{(17)}, \mathrm{de}^{-}$ tergent ${ }^{(13,24)}$, hydrogen peroxide ${ }^{(13)}$, povidone iodine ${ }^{(17)}, 4 \%$ chlorhexidine ${ }^{(17)}$, phenolic ${ }^{(19)}$. It was equivalent to $2 \%$ qua- ternary ammonium ${ }^{(12)}$ chlorhexidine $^{(12)}$, formaldehyde ${ }^{(12)}$, ethanol ${ }^{(25)}, \mathrm{NaOH}^{(25)}$, peracetic acid ${ }^{(15)}$, hydrogen peroxide $^{(16)}$, aldehydes ${ }^{(19)}$, and phenol in the presence of large amounts of organic matter ${ }^{(14)}$. And it was less than the hydrogen peroxide under dry steam ${ }^{(21)}$ hydrogen peroxide ${ }^{(16)}$, chlorhexidine $^{(18)}$, and chlorhexidine with cetrimide ${ }^{(18)}$.

All studies are controlled trials, thus, all of them performed interventions that included product testing and established comparisons. Only three assessed their interventions, two considering before and after with randomization ${ }^{(20-21)}$, and a cross-over without mentioning randomization $^{(24)}$. The randomization has been done to the surfaces for comparison of applying different products. However, authors who reported randomization in the methodology, recognized in the conclusion that this was not a randomized controlled trial, but only before-and-after randomization ${ }^{(20)}$.

While all studies have used a single type of investigation (controlled trial), meta-analysis was not adequate due to the variety of resources used in conducting the interventions, regarding the source, types of microorganisms, collecting materials, means of microbial culture, surfaces, products, concentrations and outcomes. It can be considered that each study used a singular intervention strategy. None of them were similar to each other. Similarly, in the internal validity analysis, the protocols available - CONSORT and TREND were not possible to apply. The content of the checklists were not adequate to the nature of the studies whose subjects were surfaces and microorganisms.

\section{DISCUSSION}

It is known that healthcare-associated infections (HAIs) represent a substantial risk to patient safety and several transmitter pathogens of these infections are on surfaces and equipment more often handled by professionals and patients. Although the direct relationship of the presence of 
pathogens in these surfaces with the transmission of HAIs is not yet sufficiently clarified, at least in specific locations and situations disinfection actions are recommended, not just cleaning ${ }^{(9)}$.

It is observed that despite being one of the most traditional disinfectants, hypochlorite remains studied and compared with other technologies and products.

It was presented that hypochlorite showed superior action or equivalence to most other products with broad microbicidal action, including spores, and progressive action as longer exposure time and concentration, especially those related to HAIs transmission.

When compared to other products, hypochlorite was equal or more effective in the majority of studies, however, it was inferior in concentration of $0.5 \%$ to the dry steam system of hydrogen peroxide ${ }^{(21)}$.

There were also contradictory results compared to chlorhexidine $^{(17-18)}$ and hydrogen peroxide ${ }^{(16)}$. The breadth and efficiency of their action were directly related to the concentration and the time employed, with variation between studies, as well as the types of microorganisms. Such situations led to varying degrees of inactivation or inhibition of microorganism growth.

Nearly all microorganisms tested corresponded to those most often responsible for occurrences of HAIs. C. difficile is the most tested ${ }^{(13,16,20-24)}$, probably for its great ability to survive in the environment. This result favors the recognition of hypochlorite action on hospital microorganisms.

The results of the direct relationship of hypochlorite action with the transmission of HAIs are questionable, because, although four studies have sought this relationship with an outcome that showed favorable results, these studies have problematic aspects in their research designs ${ }^{(20,22-24)}$. For example, all compared the infection rates before and after the intervention, they did not control for confounding variables, mainly related to intrinsic and extrinsic risk factors. Two of them recognize this limitation ${ }^{(20,23)}$.
Even so, despite obtaining significant reductions of environmental contamination $(66.5 \%)$ and new colonization (24.8\%). The others did not help determine if intervention occurred only with the use of hypochlorite or if there were also changes in techniques and cleaning frequency ${ }^{(13,22)}$.

Thus, the 14 included studies responded favorably to the question of this systematic review, in relation to the antimicrobial action of hypochlorite, but not in reducing the occurrence of HAIs, so there is no way to conclude by evidence, either through meta-analysis, or by internal validity analysis.

Most studies of this review sought to detail the stages of the investigation; however, none of them presented references or standards for previously validated experimental procedures, determining extremely variable strategies. Moreover, although they constitute comparative studies, none of them had strict care control for confounding variables ${ }^{(26)}$.

Even if the use of sodium hypochlorite present efficiency in its action against microorganisms associated with HAIs transmission, several issues still hinder the development of a protocol for safe use, including, especially, a relationship between concentration, action time, type and resistance of the microorganism, type and concentration of dirty.

\section{CONCLUSION}

Sodium hypochlorite presents undeniable microbicidal action on causative agents of HAIs. It was not possible to complete their direct participation in reducing colonization and/or transmission of HAIs, due to methodological problems of the analyzed studies, mainly related to the control of confounding variables. Overall, the studies in this review have extreme methodological variations, which was not sufficient to conclude that evidence to be prepared a hypochlorite application protocol that includes specific conditions of time of action, concentration and type of microorganism. At the same time, it urges the development of protocols to analyze the internal validity of microbiological experimental studies that precisely allow the evidence sought in this review.

\section{RESUMO}

Objetivo: Buscar evidências sobre a eficiência do hipoclorito de sódio em superfícies ambientais na redução de contaminação e prevenção de infecção associada à assistência à saúde-IRAS. Método: Revisão sistemática em conformidade com a Colaboração Cochrane. Resultados: Foram analisados 14 estudos, todos experimentais controlados, publicados entre 1989-2013. A maioria resultou em inibição de crescimento microbiano. Alguns apresentaram redução de infecção, da resistência microbiana e da colonização, perda de eficiência na presença de sujidade e vírus secos reidratados. Conclusão: $\mathrm{O}$ hipoclorito constitui desinfetante efetivo, todavia persiste a questão da relação direta com a redução de IRAS. A ausência de controle de variáveis de confusão nos estudos analisados impossibilitou a metanálise. Não foi possível avaliação de validade interna pelos CONSORT e TREND, pois seus conteúdos não se mostraram apropriados às investigações realizadas, laboratorial e microbiológica. Em razão disso, urge a necessidade de desenvolvimento de protocolo específico para avaliação de estudos dessa natureza.

\section{DESCRITORES}

Desinfecção; Hipoclorito de Sódio; Instituições de Saúde; Infecção Hospitalar; Revisão.

\section{RESUMEN}

Objetivo: Buscar evidencias acerca de la eficiencia del hipoclorito de sodio en superficies ambientales en la reducción de contaminación y prevención de infección asociada con la asistencia a la salud-IRAS. Método: Revisión sistemática en conformidad con la Colaboración Cochrane. Resultados: Se analizaron 14 estudios, todos experimentales controlados, publicados entre 1989-2013. La mayoría resultó en inhibición de crecimiento microbiano. Algunos presentaron reducción de infección, de la resistencia microbiana y la colonización, pérdida de eficiencia en la presencia de suciedad y virus secos rehidratados. Conclusión: El hipoclorito constituye desinfectante efectivo. Sin embargo, persiste el tema de la relación directa con la reducción de IRAS. La ausencia de control de variables de confusión en los estudios analizados imposibilitó el metanálisis. No fue posible la evaluación de validez interna por los CONSORT y TREND, pues sus 
contenidos no se mostraron apropiados para las investigaciones llevadas a cabo, tanto de laboratorio como microbiológicas. En virtud de eso, urge la necesidad de desarrollo de protocolo específico a fin de evaluar los estudios de esa naturaleza.

DESCRIPTORES

Desinfección; Hipoclorito de Sodio; Instituciones de Salud; Infección Hospitalaria; Revisión.

\section{REFERENCES}

1. Spaulding EH. Chemical disinfection of medical and surgical materials. In: Lawrence C, Block SS, editors. Disinfection, sterilization, and preservation. Philadelphia: Lea \& Febiger; 1968. p. 517-31.

2. Garner JS, Favero MS. CDC guidelines for the prevention and control of nosocomial infections. Guideline for handwashing and hospital environmental control, 1985. Supersedes guideline for hospital environmental control published in 1981. Am J Infect Control. 1986;14(3):110-29.

3. Centers for Disease Control (CDC). Guidelines for prevention of transmission of human immunodeficiency virus and hepatitis B virus to health-care and public-safety workers. MMWR Morb Mortal Wkly Rep. 1989;38 Suppl 6:1-37.

4. Sehulster L, Chinn RY; Centers for Disease Control, Healthcare Infection Control Practices Advisory Committee. Guidelines for environmental infection control in health-care facilities. MMWR Recomm Rep. 2003;52(RR-10):1-42.

5. Rutala WA, Weber DJ; Centers for Disease Control, Healthcare Infection Control Practices Advisory Committee. CDC Guideline for Disinfection and Sterilization in Healthcare Facilities, 2008. Atlanta: CDC; 2008.

6. Favero MS, Bond WW. Chemical disinfection of medical and surgical materials. In: Block SS, editor. Disinfection, sterilization, and preservation. 5th ed. Philadelphia: Lippincott Williams \& Wilkins; 2001. p. 881-917.

7. Weber DJ, Rutala WA. Environmental issues and nosocomial infections. In: Wenzel RP, editor. Prevention and control of nosocomial infections. Baltimore: Williams \& Wilkins; 1997. p. 491-514.

8. Dettenkofer M, Wenzler S, Amthor S, Antes G, Motschall E, Daschner FD. Does disinfection of environmental surfaces influence nosocomial infection rates? A systematic review. Am J Infect Cotrol. 2004;32(2):84-89.

9. Loveday HP, Wilson JA, Pratt RJ, Golsorkhi M, Tingle A, Bak A, et al. epic 3: national evidence-based guideline for preventing healthcareassociated infections in NHS Hospitals in England. J Hosp Infect. 2014;86 Suppl 1: S1-70.

10. Jarlais DCD, Lyles C, Crepaz N. Improving the reporting quality of non-randomized evaluations of behavioral and public health interventions: the TREND statement. Am J Public Health. 2004;94(3):361-6.

11. Schulz KF, Altman DG, Moher D. Consort 2010 Statement: updated guidelines for reporting parallel [Internet]. [cited 2014 May 15]. Available from: http://www.equator-network.org/reporting-guidelines/consort/

12. Campos GB, Souza SG, Lob OTN, Silva DC, Sousa DS, Oliveira PS, et al. Isolation, molecular characteristics and disinfection of methicillinresistant Staphylococcus aureus from ICU units in Brazil. New Microbiol. 2012;35(2):183-90.

13. Fawley WN, Underwood S, Freeman J, Baines SD, Saxton K, Stephenson K, et al. Efficacy of hospital cleaning agents and germicides against epidemic Clostridium difficile strains. Infect Control Hosp Epidemiol. 2007;28(8):920-5.

14. Bloomfield SF, Miller EA. A comparison of hypochlorite and phenolic disinfectants for disinfection of clean and soiled surfaces and blood spillages. J Hosp Infect. 1989;13(3):231-9.

15. Svidzinski AE, Posseto I, Pádua RAF, Tavares TR, Svidzinski TIE. Eficiência do ácido peracético no controle de staphylococcus aureus meticilina resistente. Ciênc Cuidado Saúde. 2007;6(3):312-8.

16. Perez J, Springthorpe VS, Sattar SA. Activity of selected oxidizing microbicides against the spores of Clostridium difficile: relevance to environmental. Am J Infect Control. 2005;33(6):320-5.

17. Silverman J, Vazquez JA, Sobel JD, Zervos MJ. Comparative in vitro activity of antiseptics and disinfectants versus clinical isolates of candida species. Infect Control Hosp Epidemiol. 1999;20(10):676-84.

18. Ekizoglu MT, Özalp M, Sultan N, Gür D. An investigation of the bactericidal effect of certain antiseptics and disinfectants on some hospital isolates of gram-negative bacteria. Infect Control Hosp Epidemiol. 2003;24(3):225-7.

19. Guimarães MA, Tibana A, Nunes MP, Santos KRN. Disinfectant and antibiotic activities: a comparative analysis in Brazilian hospital bacterial isolates. Braz J Microbiol. 2000;31(3):193-9.

20. Orenstein R, Aronhalt KC, McManus JE Jr, Fedraw LA. A targeted strategy to wipe out Clostridium difficile. Infect Control Hosp Epidemiol. 2011;32(11):1137-9.

21. Barbut F, Menuet D, Verachten M, Girou E. Comparison of the efficacy of a hydrogen peroxide dry-mist disinfection system and sodium hypochlorite solution for eradication of Clostridium difficile spores. Infect Control Hosp Epidemiol. 2009;30(6):507-14.

22. Hacek DM, Ogle AM, Fisher A, Robicsek A, Peterson LR. Significant impact ofterminal room cleaning with bleach on reducing nosocomial Clostridium difficile. Am J Infect Control. 2010;38(5):350-3.

23. McMullen KM, Zack J, Coopersmith CM, Kollef M, Dubberke E, Warren DK. Use of hypochlorite solution to decrease rates of Clostridium difficile-associated diarrhea. Infect Control Hosp Epidemiol. 2007;28(2):205-7.

24. Wilcox MH, Fawley WN, Wigglesworth N, Parnell P, Verity P, Freeman J. Comparison of the effect of detergent versus hypochlorite cleaning on environmental contamination and incidence of Clostridium difficile infection. J Hosp Infect. 2003;54(2):109-14.

25. Terpstra FG, van den Blink AE, Bos LM, Boots AG, Brinkhuis FH, Gijsen E, et al. Resistance of surface-dried virus to common disinfection procedures. J Hosp Infect. 2007;66(4):332-8.

26. Larson E, Cortazal M. Publication guidelines need widespread adaption. J Clin Epidemiol. 2012;65(3):239-46. 